\title{
"Slumification" of Consolidated Informal Settlements: A Largely Unseen Challenge
}

\author{
Awais Azhar1, Holly Buttrey², Peter M. Ward ${ }^{3}$ \\ ${ }^{1}$ Department of Community and Regional Planning at the School of Architecture, The University of Texas at Austin, Austin, TX, \\ USA \\ ${ }^{2}$ Carleton College, Northfield, MN, USA \\ ${ }^{3}$ Emeritus Professor, The Lyndon B. Johnson School of Public Affairs, and College of Liberal Arts, Department of Sociology, \\ Emeritus C.B Smith Sr. \# 1 Centennial Chair in US-Mexico Relations, The University of Texas at Austin, Austin, TX, USA \\ Email: awais.azhar@utexas.edu, hbuttrey@carleton.edu,peter.ward@austin.utexas.edu
}

How to cite this paper: Azhar, A., Buttrey, H., \& Ward, P. M. (2021). "Slumification" of Consolidated Informal Settlements: A Largely Unseen Challenge. Current Urban Studies, 9, 315-342.

https://doi.org/10.4236/cus.2021.93020

Received: June 13, 2021

Accepted: July 13, 2021

Published: July 16, 2021

Copyright $\odot 2021$ by author(s) and Scientific Research Publishing Inc. This work is licensed under the Creative Commons Attribution International License (CC BY 4.0).

http://creativecommons.org/licenses/by/4.0/

\begin{abstract}
Today most scholars, policy makers, and low-income "slum" residents themselves eschew the term slum and some argue that it is high time to retire the term altogether. We agree, and yet recent research of consolidated informal settlements in Latin America and the United States suggests that the conventional wisdom of successful self-building trajectories is sometimes severely constrained, or stymied altogether. In this paper we analyze why some types of housing may enter a downward decline of deterioration, into what might constitute the erstwhile term of a slum, after having successfully consolidated over 20 or more years. This paper draws upon a nine-country study through the Latin American Housing Network or LAHN

(https://www.lahn.utexas.org/) of low-income housing in Latin America with comparisons to Texas, USA. Examples from the former comprise of different types of consolidated settlements that are located in the "innerburbs" or "first suburbs" today, and where some authors argue there is a need for new policy imperatives of housing and community rehab to overcome deterioration and dilapidation. Despite the apparent success of self-building consolidation since the 1960s and 1970s, we are now beginning to observe evidence of heavy distress to the physical fabric of dwellings and communities, a process that may be considered de facto "slumification". This process is triggered through structural changes under neoliberalism and the "poverty of resources," heterogeneity of land access, physical constraints and deterioration, the lack of legal titles and title clouding, densification and stress on the built environment, environmental hazards, and natural and man-made disasters. However, in part, slumification occurs due to the failure of policies to respond to deteriorated housing conditions after years of intensive use. Unless policies ad-
\end{abstract}


dressing the triggers of slumification are addressed, we argue that today's consolidated informal settlements may very well become the slums of the future.

\section{Keywords}

Informal Housing, Slum Terminology, Latin American Cities, Public Policy and Housing Rehab, Neighborhood Densification

\section{Introduction: Return of the "Slum" Part II?}

To many readers who are familiar with the scholarly literature from the Global South since the 1970s and 1980s, and especially that which emanated from Latin America as cities urbanized rapidly from the 1960s onwards, the title of this paper may come as something of a surprise. Research by numerous scholars and practitioners in the late 1960s through the 1970s explored the nature and role of informal self-help housing in Latin America and formed part of the emerging canon of thinking that argued that these areas often were not slums. Although these areas did comprise very poor housing conditions, they showed strong possibilities for physical of improvement over time, eventually being integrated into the city fabric as working-class settlements. These neighborhoods displayed an "architecture that works" (Turner, 1968); and were expressions of "rationality in the slum" (Portes, 1972), rather than those of a "culture of poverty" (Lewis, 1966) and of palpable urban and social pathologies of housing conditions and vagrancy.

These ideas were, themselves, flashbacks to the nineteenth and early twentieth century "slum" constructions in the USA, Europe and elsewhere (Mayne, 2017). The slum and migrant population stereotypes were, in fact, a "myth of marginality" (Perlman, 1976); they were "slums of hope" rather than "slums of despair" (Stokes, 1962; Lloyd, 1979). Indeed, the first journal article published by one of us (Ward, 1976) in Land Economics in 1976 was entitled: "The Squatter Settlement as Slum or Housing Solution?", which, for the case of Mexico City contrasted the inner-city rental shanties with little hope of development, the socalled lost city rental shackyards called ciudades perdidas (INVI, 1968), with the wider universe of peripheral self-help land captures and rapidly expanding informal settlements that formed an entry point to informal ownership and selfbuilding, even while comprising precarious shacks and motley provisional dwelling structures in the first instance. Indeed, many contemporary authors in the 1970s into the 1980s sought to argue a more positive case for the housing development under structuralist conditions of poverty rather than cultural ones, displacing the modernization school of the 1960s and Oscar Lewis-type cultural explanations (Turner, 1976; Leeds \& Leeds, 1976; Portes, 1979; Ward, 1982; Gilbert $\&$ Ward, 1985). 
The first UN-Habitat meeting in Vancouver in 1976 proved to be a turning point in beginning to shift views of informal settlements away from their being slums inviting large scale eradication and neighborhood regeneration programs towards a more positive policy stance, which from the early 1980s largely prevailed. Indeed, it became conventional wisdom and encouraged intervention strategies such as "upgrading" and "regularization," or the provision of basic infrastructure, sometimes in tandem with conferring property titles upon squatters and other de facto, but not de jure, owners (Reyes et al., 2020). Crucial here was that multilateral organizations, such as the World Bank and UN, largely began to eschew the term "slums", preferring to use other less pejorative terms such as informal settlements, spontaneous settlements, or irregular settlements. While the term often persisted in the literature and in policy debates in Africa and South Asia where poverty levels were higher and urbanization was less advanced, the term slums had largely disappeared from terminology in Latin American academic and policy writing, as well as in the majority of formal UN documents, at least for the two decades of the 1980s and 1990s.

However, purging use of the term slum was short lived, and it returned into widespread use at the turn of the $21^{\text {st }}$ century spurred by contexts where selfhelp and informal settlements were not consolidating or improving over time, but appeared to be stuck in impoverished conditions. Books such as Planet of Slums (Davis, 2006), leadership changes in UN-Habitat and the resurgence of policy approaches to create "cities without slums", films like Slum Dog Millionaire, prompted Alan Gilbert (2007) to write: "The Return of the Slum: Does Language Matter?" in the International Journal of and Urban Regional Research. ${ }^{1}$ His argument was that it does, of course. Reverting to slum terminology is dangerous for three overarching reasons: First it reasserts and reproduces pejorative and negative associations of squalid living conditions; cultural stereotypes of the people living in inner-city neighborhoods, often as an underclass; and as loci of deviance, crime and criminality. Second, it ignores the fact that slums are heterogenous: some are fully serviced others are only partially integrated into the city infrastructure, and as such the term is highly relative both between housing conditions and criteria in different regions of the world, and between neighborhoods within a single city. Moreover, informal settlements change over time: levels of dwelling consolidation vary between and within settlements; the population becomes more mixed, as do tenure patterns. Heterogeneity is the rule, not the exception, and as such the concept is highly relative. Third, the term invokes dangerous and perverse solutions such as evictions and demolition, widespread redevelopment and, where accompanied by resettlements into social housing programs often leads to the marginalization of populations whose social networks upon which they survive are undermined. Gilbert also suggests that it creates a ${ }^{1}$ In acknowledgement of Gilbert's paper, the working paper on which the current paper is based flags the idea of a Return of the Slum II. The working paper may be accessed on ResearchGate: https://www.researchgate.net/publication/341322830_The_Return_of_the_Slum_II_Tipping_Points _That_Undermine_Low-Income_Housing_and_Neighborhood_Consolidation. 
paradox of providing solutions that are unattainable.

So why in this paper do we return to slum labelling at a time when Gilbert and others are questioning the helpfulness of the term, and when Alan Mayne is arguing in his 2017 book, Slums: A History of Global Injustice, that it is time to retire the term? We do so, not because we disagree and do not sympathize strongly with such arguments: indeed, much of the career of one of us (Ward) has been largely vested in research to divert stereotypical views away from the notion of slums, and to promote public policies in Latin America and elsewhere to improve housing conditions through self-help and community development. Truth be told, we have come reluctantly to the arguments presented in this paper in which we offer some insights about how, if informal settlements in the Global South and North did not truly represent the slums in the past, they are in danger of becoming slums of the future. They do so because of various "triggers" that lead to processes of neighborhood decline and deterioration of the housing stock, and we offer a new analytical term to the housing lexicon to refer to this process, "slumification". The term is a translation of the Spanish verb "tugurización", which described the creation and expansion of "tugurios" as the inner-city slums of Mexico City and other Latin American literature were called during the 1940s to 1960s (INVI, 1958).

Our concerns have emerged largely from observations drawn from a major research enterprise, the Latin America Housing Network study (LAHN https://www.lahn.utexas.org/), in which a number of us have been engaged. This research focuses upon the nature of housing and life chance trajectories of second and third generation low-income city dwellers born to those original informal settlers of the 1960s through 1980s. In the LAHN, the unit of analysis focuses upon those consolidated settlements of yesteryear, no longer peripheral, but in what Ward, Jiménez and Di Virgilio (2015a) term the "innerburbs". These are the first ring of suburbs (mostly informal settlements) of Latin American cities that formed in the 1960s to1980s, and while different in nature, they are akin to "first suburbs" of many US Cities (Brookings Institution, see Katz, Lang and Berube, 2006). These first-ring suburbs were developed after the Second World War during the 1950s \& 1960s and today are often physically distressed, forming locations with the "new poverty", inequality, de facto residential segregation, and underlying racism in many US metro areas (Kneebone \& Berube, 2013; De la Rocha et al., 2004). ${ }^{3}$

In this paper we present broad-brush findings about the ways in which a variety of triggers are leading to deterioration and slum-like conditions. While we

${ }^{2}$ The idea of slumification was first pitched by Peter Ward at a major seminar on "Slums: New Visions for an Enduring Global Phenomenon", organized by the Lincoln Institute of Land Policy and the Joint Center for Housing Studies at Harvard Graduate School of Design, September 20 to 22, 2018. It then became the basis of a UT-Austin Spring graduate class, Housing Practices and Policies in LA, led by Peter M. Ward.

${ }^{3}$ The case of Ferguson, St Louis (Missouri) is a classic case of a first-ring suburb (now incorporated city), made famous in August 2014 after the police office killing of Michael Brown. 
focus primarily upon informal settlements in both the Global South and in the USA (Ward, 2012b), we will also comment upon emerging slum conditions that we observe in the low-income mass social interest housing estates that burgeoned in many Latin American cities from the mid-1990s onwards.

\section{Informal Settlement: A Solution?}

The idea that informal self-building was a "housing solution" was always something of overstatement, not least since self-help and self-management of one's housing carried, and continues to carry, significant social costs and household sacrifice. Moreover, definitive solutions to housing poverty, and poverty in general, require structural change, rather than "bootstraps" approaches of self-help and spontaneous community development. Indeed, many of those advocating for more pragmatic self-help housing solutions in the 1970s (e.g. John F. C. Turner and others), recalibrated their thinking, an example of which is the edited volume Self-help housing: a critique (Ward, 1982; See also Mathey, 1992). Moreover, not all informal settlers of the 1970s to the 1990s successfully, or extensively, consolidated their homes. Informal neighborhoods (barrios, favelas, colonias, ) were, and are to this day, quite heterogeneous. There were always some shanty improvised dwellings with slum-like conditions that were hidden behind the street front boundary wall. In addition, there is scant data on what proportion of aspirant self-builders were unsuccessful and exited, and to our knowledge, no study has tracked individual informal settlement families and documented those who quit early on. ${ }^{4}$ Some may not make it, but generally the opposite is true, and once on the path towards homeownership most pioneer self-builders ultimately achieve their goals of creating a patrimony, and successfully built-out their homes over time. Significant, also, is the fact that according to research, the majority were still in those same lots some 25 to 40 years later (Gilbert, 1999; Ward, 2012a).

Many of the ideas presented in this paper draw upon the Latin American Housing Network (LAHN) study which embraces nine countries and eleven cities. Using a common methodology, the various research teams explored the contemporary nature of household organization and housing needs. This included developing an understanding of second and third generation aspirations of those

${ }^{4}$ That said, in one study, Ward, Way and Wood (2015b) were able to estimate early would-be self-builder exits in their work on land capture \& self-building among Texas border colonia residents in Maverick County. In the study, by tracking developer lot sales contracts ("Title for Deed"), the researchers found that almost half of those who originally started payments on a lot did not successfully establish a home and work through to receiving full title (i.e., when they paid off the contract usually after 8 - 10 years). We suspect that such failure to consolidate a home has been widespread in Texas colonias and other informal subdivisions. Furthermore, in another set of studies in so-called model subdivision communities targeting self-builders in Hidalgo County, Texas, the amortization costs of land purchase and services stymied successful consolidation, leading to some of the worst housing conditions along the border, slums in all but name (Olmedo \& Ward, 2016). Among those seeking to become homeowners, there are high levels of failure, exit, and developer repossession. As "renting to own" homesteading is becoming one widespread policy option, it is important to view these as "owning to (de facto) rent". 
living in these consolidated innerburb neighborhoods today: as owners, renters, and adult children sharing housing with aging "pioneer" self-builder parents who forged the settlement 30 to 50 years ago. From the outset, a central goal of the LAHN was to figure out the public policy and housing challenges facing these consolidated neighborhoods. Surely, rather than the provision of basic infrastructure that formed the physical policy needs and regularization policies of the 1980s and 1990s, the challenge would be one of recasting the built-out spaces in the homes? This would be critical in order to accommodate new user needs, to rehab and retrofit services, and to ensure asset management for owners whose properties now had significant exchange value, in addition to meeting ongoing use values. In addition, a key question was regarding what would happen to these home assets when those pioneer owners passed away? Researchers who were part of the LAHN sought to address these policy challenges in the volume Housing Policy in Latin American Cities: A New Generation of Strategies and Approaches for 2016 UN-Habitat III. The important point to underscore here is that these policies were primarily related to housing and community rehab in the innerburbs, while at the same time promoting resistance to rising pressures of displacement and gentrification in what are often well-located working-class neighborhoods.

To return to the idea of slumification, our reading of the LAHN study data that we gathered across multiple cities through GIS mapping, surveys, intensive case studies, and other methods, alerted us to several common trends. First, densification had occurred in these now prime-located neighborhoods as low-income rental housing markets have been developed, and as some of the adult children born in the barrio remained with their parents and raised their own families. Due to these changes, population densities of 450 to 500 persons per hectare are commonplace in these communities. Second, overcrowding had proliferated among young renter households in new forms of rental tenements, and for adult children with their own young families that lived in secondary household units which were often a room or two built in the lot. Third, there was considerable deterioration and distress of the physical fabric of the dwellings since they were gradually constructed over time and had had few home improvements even after 30 or more years of intensive use. The deterioration had been exacerbated by inadequate water, drainage, and electric infrastructure that were designed for much lower population loads and without adequate concerns for safety. Fourth, the outdated dwelling design and space usage were unable to respond to contemporary needs and privacy concerns, particularly as the houses had gradually grown to accommodate changing needs of expanding families with limited capacity to invest. Finally, the "clouding" of property titles complicated ownership and reduced the incentives and capacity needed to remodel and invest in the home. This sometimes resulted from informal inheritance patterns, as adult children became heirs to property that had been regularized in the name of the parents.

As mentioned above, not all settlements consolidate, and even for those that 
do, one finds some households living in extremely poor housing with little upward physical mobility (Figure 1). But other things being equal there was widespread acceptance of the idea that informal settlements did upgrade over time and that there was an upward curve of neighborhood and home improvements. Even if such an upward trajectory was sometimes steep, and sometimes with fits and starts, depending upon the economy, city location and visibility, public perceptions and propensity to intervene to support or to threaten the fledging community, community mobilization to work on behalf of the community, etc. Once integration into the fabric of the city was well underway, mobilization and community participation declined, and the rate of upgrading slowed with the consolidation curve flattening (see Figure 1).

The results of the LAHN study suggests that after 25 to 40 years a "tipping point" may be reached where many of the general consolidation processes alluded to above threaten to turn the curve downwards. This is likely to happen unless there are concerted efforts to mobilize housing and community rehab policies, provide financing for retrofitting and undertaking home alterations, re-galvanize community efforts around rehab, and promote the production or conversion of housing for low-income renters (see Figure 1). Not all homes experience this downward spiral of deterioration, considering that households who can afford it make major upgrades and conversions so that the dwelling fits more squarely with the needs of the household, or multiple households. Other households sell their dwellings and better-off newcomers convert or tear down

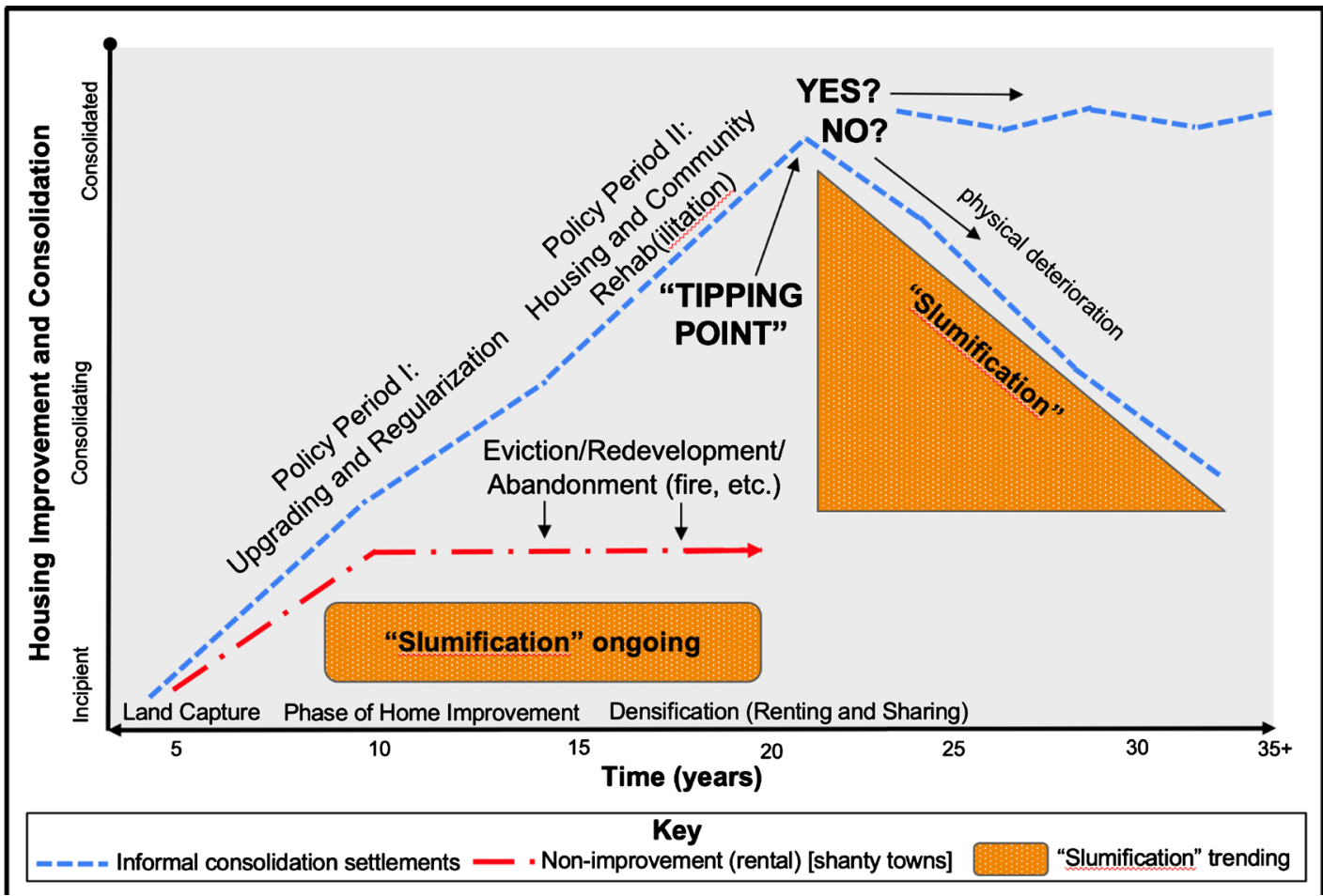

Figure 1. Trajectories of Consolidation and Possible Slumification in the Absence of Policies of Housing and Community Rehabilitation. (Diagram courtesy of Holly Buttrey and Sophie Morse). 
and start over. Given the now-prime innerburb location of these dwellings, developers sometimes buy out entire blocks or multiple adjacent lots in order to develop gated apartment buildings, thus leading to new processes of displacement and "pocket gentrification," albeit an exception rather than the rule (Varley, 2014). ${ }^{5}$ Although largely a feature of the 1960s and 1970s, public sector urban regeneration projects have also led to mass clearance and displacement. However, in such cases the replacement housing projects were themselves also not immune to subsequent degradation, slumification, and teardowns.

\section{Slumification: "Triggers" In the Physical Deterioration of Consolidated Settlements}

As described above, policies aimed at consolidating informal settlements have been widely touted by researchers, advocates, and some policymakers as the key to support informal settlements and their residents. Consolidation, through self-help strategies, upgrading and site-service-schemes, can have a significant impact on the quality of life for residents by providing legal support, infrastructure development, and dwelling improvements. As important as initial consolidation efforts have been for supporting the residents of informal settlements, without further attention and support these settlements may decline into slums as the infrastructure and housing stock deteriorates. It is imperative then, that research and policymaking address this process of slumification, and better understand the triggers whereby housing conditions in consolidated settlements can worsen over time. In this section of the paper, we explore some of these triggers.

\subsection{Trigger Factor \# 1: Structural Changes Under Neoliberalism and the "Poverty of Resources"}

The first trigger is the lack of structural changes that would lead to improving economic conditions and reduction in urban poverty levels. In the 1980s Latin American countries faced a financial crisis as countries were unable to pay off foreign debt. In response to the crisis, and with the guidance of Washington-based institutions like the World Bank and International Monetary Fund, Latin American countries adopted neoliberal policies that have had long-lasting impacts on residents (Hackworth, 2007; Klaufus, 2015; Reyes, et al., 2020). Neoliberal processes have been cast in the light of a "roll-back" and "roll-out" phase, where welfare policies aimed at assisting poor and low-income communities are

\footnotetext{
${ }^{5}$ A term coined by Prof. Ann Varley of the University College London Department of Geography and introduced at the Lyndon B. Johnson School of Public Affairs Mid-Semester International Workshop "Housing Market Function and Dysfunction in Consolidated Self-help neighborhoods: Towards Smart Densification", March 18 to 19, 2014. See also the Working Paper: Urban Regeneration, Housing Rehabilitation \& Densification Without Displacement in Latin American Cities. Chen Yu, et al. ResearchGate https://www.researchgate.net/publication/304076761 URBAN REGENERATION HOUSING RE HABILITATION DENSIFICATION WITHOUT DIPLACEMENT IN LATIN AMERICAN CI TIES.
} 
first dismantled and then neoliberal practices are implemented in their place (Hackworth, 2007: p. 12). Harvey (2006) clarifies the stated political motivations behind such restructuring:

The neo-liberal state looks to further the cause of and to facilitate and stimulate (by tax breaks and other concessions as well as infra-structural provision at state expense if necessary) all business interests, arguing that this will foster growth and innovation and that this is the only way to eradicate poverty and to deliver, in the long run, higher living standards to the mass of the population. (p. 25)

However, as Klaufus (2015) explains, "the liberal reforms and cutbacks that resulted in unemployment were paralleled by an increase in poverty, social insecurity and urban violence" (p. 5). Neoliberal policies, such as austerity measures and decreased state-driven social services, exacerbated poverty, rather than raising the standard of living. With urban residents struggling to support their families and afford housing, there was an increase in precarious housing conditions and deterioration.

As outlined earlier, in response to literature that pathologized the poor, researchers have argued that families in Latin America are able to overcome challenges even when faced with harsh economic conditions, poor macroeconomic policies leading to unemployment, and a reduction of social services under neoliberalism. This belief in the "resources of poverty" focuses on the ingenuity and survival skills of the poor who are able to survive all hardships based on their ability to work endlessly, employ cost-saving strategies, and create community self-help approaches (González de la Rocha, 2007: p. 72). Mercedes González De la Rocha argues that this capacity to survive has been manipulated to further advance neoliberal policies (González de la Rocha, 2007). However, the bottom line is that these neoliberal policies have ultimately reduced access to jobs and wages for the urban poor in Latin America. The formal job market is increasingly constrained, while the informal job market continues to expand.

Questioning and understanding the economic challenges faced by the urban poor requires us to move from a resources of poverty model to a poverty of resources model (González de la Rocha, 2001: p. 72; González de la Rocha et al., 2004). The former focused exclusively on financial practices within low-income households and their social networks which allowed families to survive even when faced with poverty. It is important to understand that the lack of employment opportunities and the precariousness of existing opportunities under current economic paradigms have resulted in a situation leading to this poverty of resources. Meaning that impoverished households not only lack capital but also, they lack opportunities because of their physical location. This poverty of resources is exacerbated by the fact that changes in the labor market have led to the deterioration of social systems that supported families living in poverty (González de la Rocha, 2001). It has also reduced the speed, extent and capacity 
of house to successfully build out and consolidate their homes.

Neoliberal reforms aimed at addressing labor shortages and the rise in informal employment in the 1980s might have improved macroeconomic performance among Latin American countries. However, neoliberal restructuring in the region, specifically urban areas, has increased income polarization, reduced job security, and increased the rates of underemployment and unemployment. As a result, informal employment remains a critical economic source for the lowincome, coupled with fewer social protections and supports (Biles, 2009). This lack of access to formal labor markets and financial insecurity among younger generations, augmented by declining wages from aging parents, has impacted the ability to access or maintain the condition of decent housing among younger generations. Challenges associated with transferring assets between generations further exacerbates the economic security of younger generations, thereby impacting their access to housing (Moser, 2009).

A lack of available capital, stemming from poverty and challenges with asset transfers, can lead to the deterioration of consolidated informal housing over time. Where residents either do not have access to capital, or all existing capital is used in accessing land, residents may not have the ability to improve housing conditions or to successful consolidate their dwelling. This may manifest itself in poor housing conditions, insufficient services, and severe deterioration over time. This lack of capital is a result of many factors associated with neoliberalism: changes in the labor market, increasing cost of accessing land, and increasing household costs. As land and consolidation costs increase, residents are less likely to spend on consolidation and maintenance efforts. If the cost of accessing land is significant, new residents will be forced to defer consolidating and, instead, continue to live in poorer housing conditions. They may also decide to further subdivide or rent a part of the property in order to support construction projects. Thus, the lack of capital and ability to create some level of investment surplus at the household level is likely to lead to significant deterioration of both housing stock and general infrastructure in informal settlements.

The important takeaway here is that these factors have increased the obstacles families face when trying to break out of poverty, with deep impacts on housing conditions and consolidation. Informal self-builders in the 1960s and 1970s, especially those who were change to: low-waged formal sector workers benefitting from import substituting industrialization (ISI) were able to invest their own sweat equity and modest savings in home construction, and many became the successful "consolidators" described by Turner and his colleagues (Turner, 1967, 1976; Abrams, 1966; Leeds \& Leeds, 1976). However, after the so called "lost decade" of the 1980s austerity and structural adjustment programs (SALS) propagated by the IMF and World Bank, and the onset of neoliberal policies, the rising proportion of informal sector workers and the second and third generations children of the pioneer self-builders found fewer opportunities and resources to follow their parents and become home-owner consolidators. Moreover, their par- 
ents are aging and the decline in their take-home resources limits the scale and extent to which they may make housing improvements and retrofits (Ward, Jiménez, \& Di Virgilio, 2015a).

The Ultimate Paradox: Slumification in Neoliberalism Newly Built Mass Social Interest Housing Projects. While neo-liberalism was reducing the opportunities for informal-sector housing expansion and dwelling consolidation, it also came up with market-based formal mass social housing ownership opportunities in order to accommodate residents from informal settlements and to counter informal employment under the discourse of alleviating poverty and inequality (Monkkonen, 2012). The State attempted to intervene with subsidies and financial structures in order to protect the formal housing market through these efforts. However, these mass-social interest housing programs are also not immune to slumification (see Figure 2), in which the triggers are social and physical segregation in distant peri-urban land tracks, ongoing economic inequality and hardship due to long bus commutes, and physical deterioration by new resident low-income families who cannot afford to make payments or home improvements (Stiphany \& Ward, 2019).

Critical issues of abandonment, physical deterioration, and urban marginalization are frequently seen in formal mass social interest housing estates across Latin America (Carvalho, 2015). This process of deterioration has been documented in social interest housing estates developed by the Institute of the National Fund for Workers' Housing (Instituto del Fondo Nacional de la Vivienda para los Trabajadores, INFONAVIT) in Mexico, where residents report issues with the poor architecture and construction, the lack of regular provision of

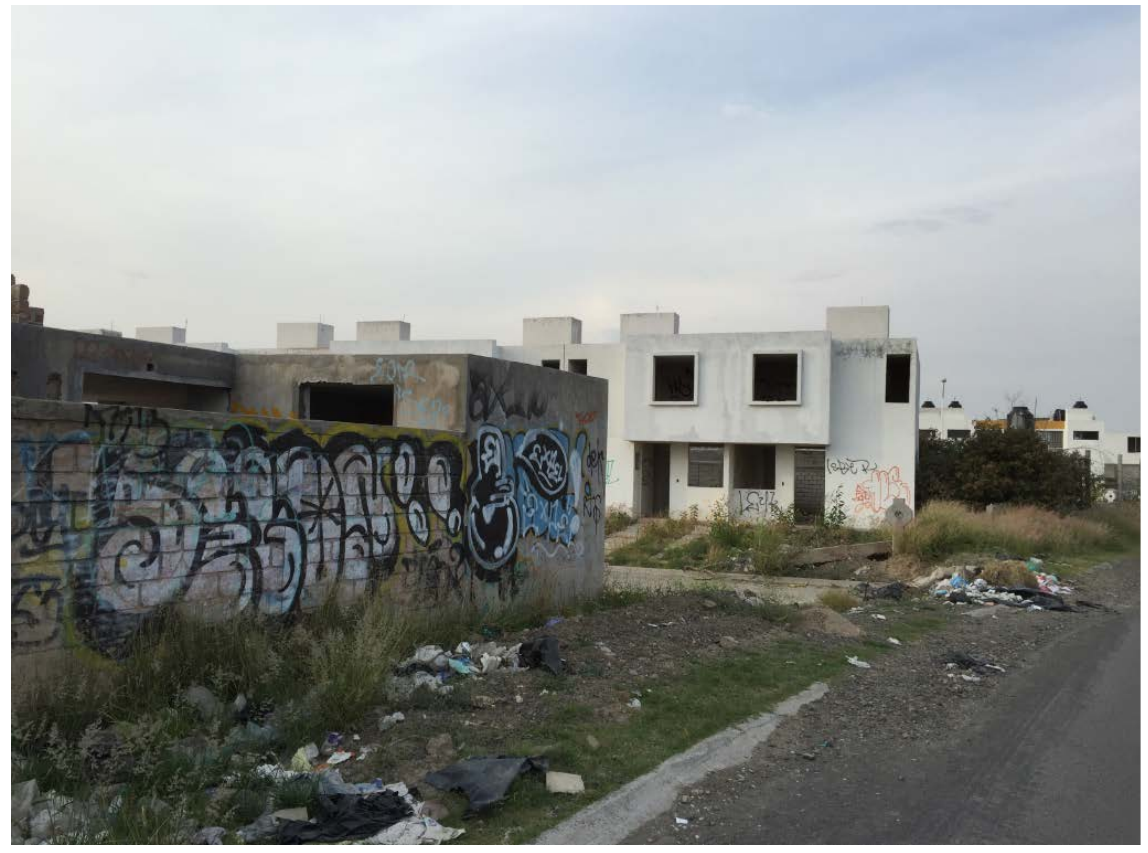

Figure 2. Slumification in sections of early 2000s mass social interest housing, Guadalajara, Caused by lack of demand and abandonment. (Photo courtesy of Dr. Yu Chen.) 
water and sanitary services, and constant power blackouts (Marosi, 2017). In such cases, neoliberal policies have led to deterioration and slumification, even in new formal housing projects designed to replace informal settlements.

\subsection{Trigger Factors II: Heterogeneity of Land Access, Physical Constraints, and Deterioration}

Informal housing settlements vary greatly depending on how the land was originally accessed or captured by residents. Illegal subdivisions are one form of land access where a developer creates and sells lots informally without the official government permits. Such settlements have been called barrios, barrios piratas, loteamentos irregulares, loteos populares, and colonias populares. Squatting is another frequently seen form of land access, where residents illegally occupy land for housing. Names for such settlements include favelas, barriadas, villas-miserias, villas de emergencia, chabolas, and tugurios (Fernandes, 2011). Squatting, and the illegal occupation of land, is often on land that can be an environmentally compromised and represents a safety hazard or is extremely difficult to build upon: essentially "residual land" that otherwise is deemed unsuited for housing development, period, let alone improvised informal self-built settlement.

Land access is integral to understanding slumification due to the constrains it can place on successful upgrading and consolidation. The lack to a proper title, resulting from the illegal capture of land or illegal subdivisions can delay regularization and heighten residents' vulnerability, thereby disincentivizing efforts at consolidation. The vulnerability stemming from enforced removal and eviction from the state can vary by location, so that residents of areas that are most likely to be captured by the state and redeveloped may be less likely to invest their savings in consolidation (Perlman, 1976). Lot characteristics, closely associated with land access, can become additional challenges because crescive and irregular areas make consolidation and rehabilitation more difficult, even in cases where there may be an incentive to consolidate (see Figure 3 and Figure 4). Lot size, shape and gradient may hamper the ability to reorganize space in situ, make infrastructural improvement or consolidate settlements (Ward, Jiménez, \& Di Virgilio, 2015a). Indeed, in the LAHN study, the authors identified two types of consolidated settlements: inner-urban crescive neighborhoods such as the Villas of Buenos Aires, and shanty towns such as El Esfuerzo in Guatemala City (Roberts, 2015). In El Esfuerzo, lots are very small, and access is difficult, compared with the broader type of consolidated settlements on larger lots with a more formal block layout (the loteos populares and colonia-type subdivisions such as La Florida, [Figure 5]). Lot and dwelling sharing, rebuilding or retrofitting services are easier to undertake where there is more space to reorganize and recast living arrangements.

Challenges associated with land access can become a significant factor contributing to housing and infrastructure deterioration. Some informal settlements are built on what we term residual land which was designated as unsafe for 


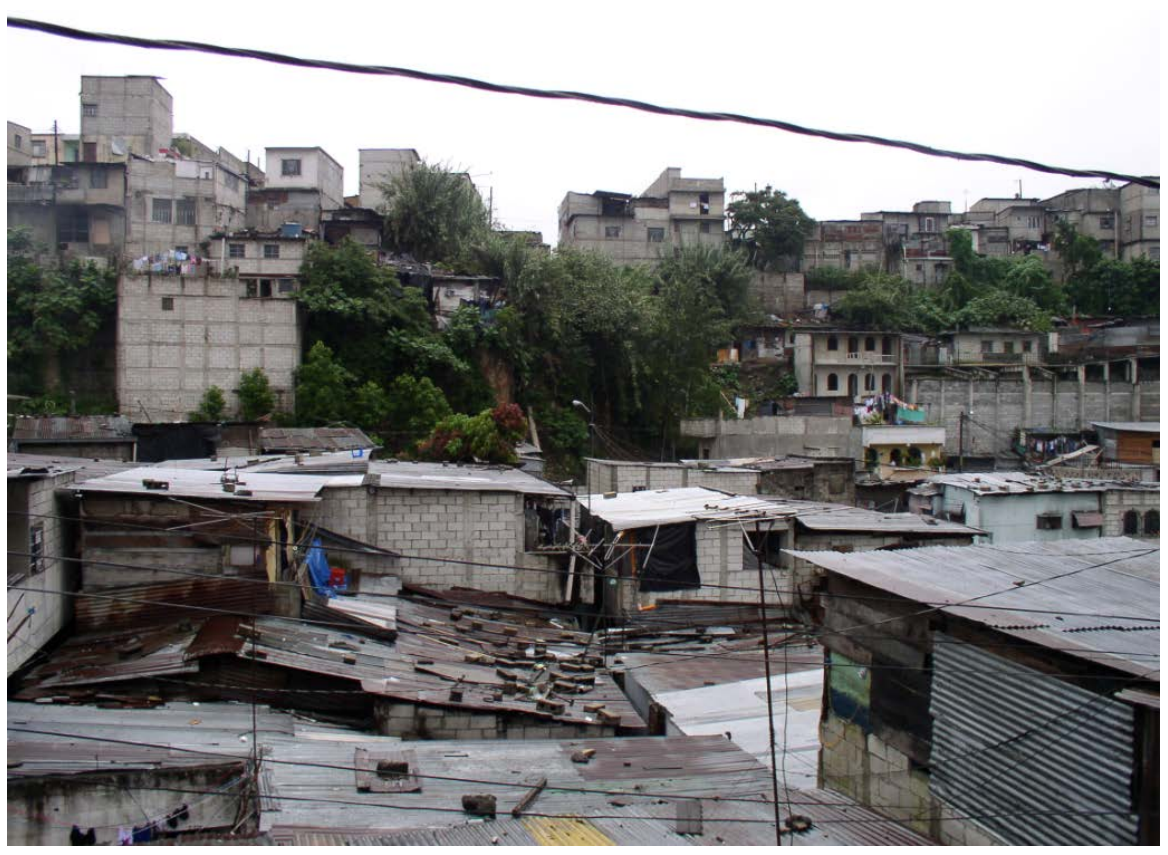

Figure 3. Inner-city consolidated shanties, El Esfuerzo, Guatemala City. (Photo courtesy Dr. Peter Ward).

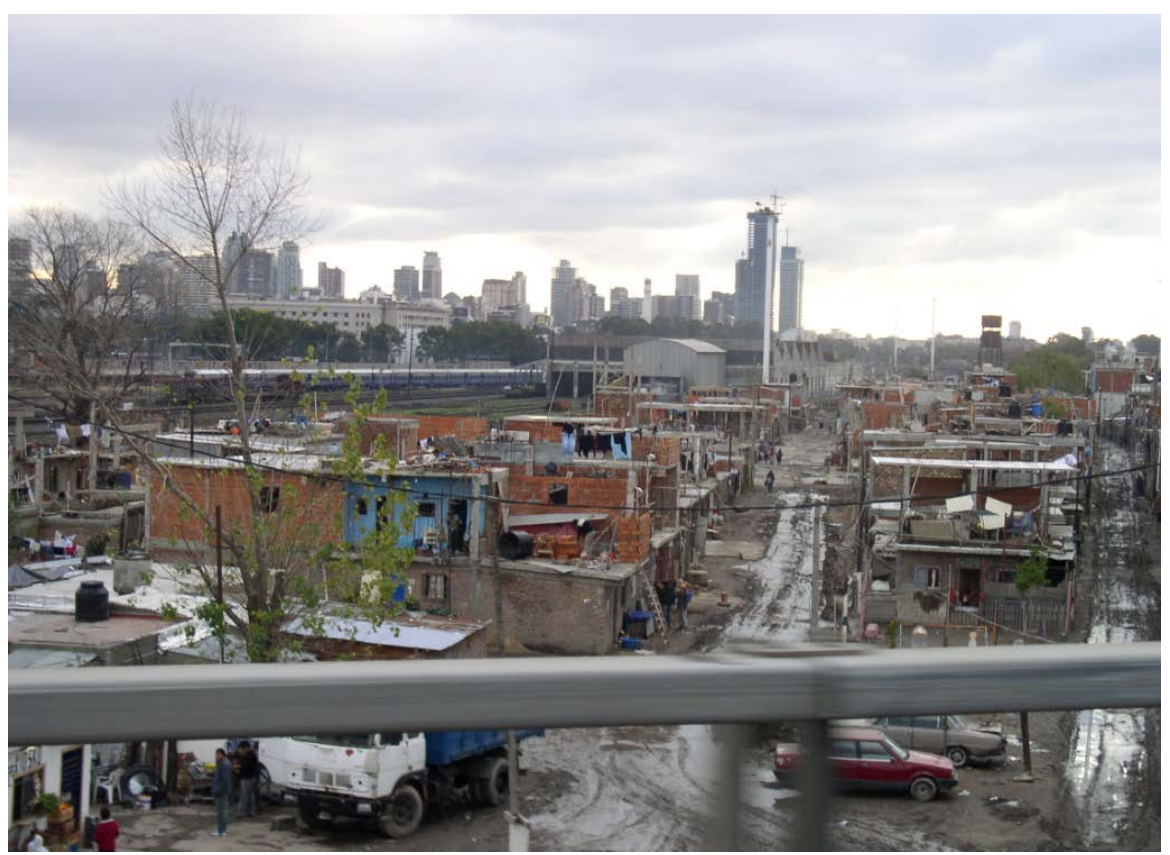

Figure 4. Villa 21, Center of Buenos Aires. (Photo courtesy Dr. Peter Ward).

habitation either because of environmental issues or safety concerns. Nevertheless, residents may illegally occupy or squat on the land because of the availability and proximity to employment opportunities. These settlements are often along ravines and creeks and in areas prone to flooding with severe environmental concerns. Additionally, they can often be located in areas that are unsafe such as along railway lines. Los Platanitos in Santo Domingo Norte in the Dominican 


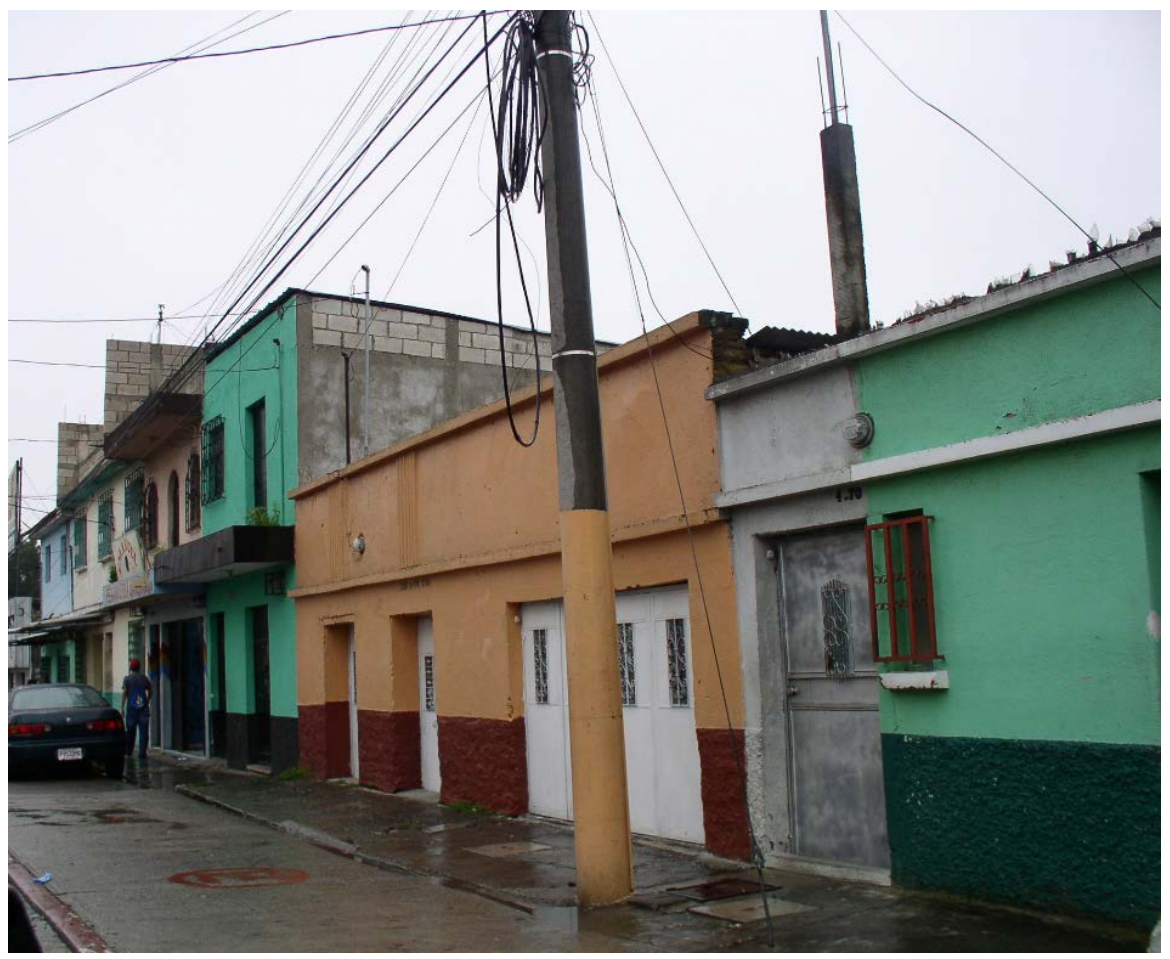

Figure 5. Colonia La Florida, innerburb consolidated settlement with large lots on a reticular plan of blocks and streets, Guatemala City. (Photo courtesy Dr. Peter Ward).

Republic is an example of an informal settlement that was first created on state land in the late 1980s and early 1990s (see Figure 10(a) \& Figure 10(b) below): indeed, the land was formerly a city landfill and as are many other informal settlements, portions are prone to flooding and landslides (Pusch, 2010: p. 32). In such cases, the residents have very little security in terms of land tenure and are less likely to improve their dwellings or pay for services. Where residents are able to gain legal title to the land through regularization, flooding and other issues such as erosion may make it very hard to substantially improve the infrastructure and consolidate over time. In the case of such settlements, not only do the residents struggle to make improvements but the state and local government may also limit consolidation efforts by refusing to recognize them and provide services.

\subsection{Trigger Factors III. The Lack of Legal Titles and Title Clouding}

Following the UN-Habitat I Congress in Vancouver, Canada, in 1976, housing policies stressed the desirability of providing titles to informal land captures, the argument being that a secure title can strengthen the foundations for individual and family wealth which subsequently provides housing security, mitigates eviction, furthers consolidation, improves housing conditions, and allows for the leveraging of property as collateral to raise capital (Turner, 1976; De Soto, 2000). Indeed, De Soto highlights the idea that poor residents in Latin America own assets but because the rights to such assets are not legally certi- 
fied, they cannot be converted to capital, traded, sold, or leveraged. Regularizing this "dead capital" is imperative to improving the quality of life for the urban poor in Latin America he argues, and to allow residents of informal settlements to consolidate their dwellings. At a macro level, formalization is necessary to ensure that the housing market works well and necessitates the need for a legal title (De Soto, 2000). In fact, title regularization is not a prerequisite for successful consolidation, and many authors have shown that recognition that nascent settlements will not be eradicated is invariably provided in other ways, often through service provision, school and market provision and other municipal supports, all of which reassure residents and stimulate investment (De Souza, 1999).

Nevertheless, policies aimed at regularizing titles have become widespread in Latin America, in part because it is a policy that is easier and less costly to implement than upgrading or physical interventions (Ward, 1999). And while in the past a lack of a clean title has not been an irrevocable barrier to consolidation, there is evidence that clean titles that have been granted as part of regularization policies are now sometimes becoming tainted or clouded, and that this may lead to disinvestment, deterioration, and, over time slumification. This title clouding occurs through inheritance, as first-generation informal settlement owner households pass on the property to second-generation and third generation residents, usually their adult children, and do so informally by word of mouth or implicit agreements. In consolidated settlements, titles become clouded with the transfer of property among heirs, particularly if the owner, in whose name a title exists, dies intestate (Ward, 2015a). Without formal title transfer of ownership via a Will or by formal contract, legal ownership becomes ambiguous and may lead to conflicts among heirs. Moser (2009) highlights the challenges of intergenerational title transfers among larger families in her study of Indio Guayas, a community on the periphery of Guayaquil, Ecuador. As she studied the families in the community over time, she found that even though the original residents had been able to gain access to clean titles, they were becoming contested or were likely to be contested by the next generation, leading to clouded titles (Moser, 2009).

A clouded title, resulting from inheritance after the owner dies intestate, reduces the incentive to consolidate or improve a dwelling because the heirs do not see a direct benefit to them (Ward et al., 2011). Furthermore, resolving the issue of the clouded title can take a long time and the heirs can incur considerable expense, thereby creating further ongoing housing insecurity, and reducing incentives to fund consolidation and housing rehabilitation. Clouded titles can also lead to a decline in the value of the asset, minimizing the ability to leverage the property for funding or selling to a buyer. In the latter case, owners wishing to sell may need to sell the property at a lower price and are unable to realize the full value of their asset. Ultimately, clouded titles can trigger deterioration in consolidated settlements even when clean titles had been obtained a generation earlier. 


\subsection{Trigger Factors IV. Densification and Stress on the Built Environment}

Most informal settlements undergo densification over time as the families of original residents grow and as new households or individual renters move into newly created rental opportunities in the settlements. Densification can manifest itself through the construction of additional structures, the subdivision of existing lots, and new forms of rental housing, often illegal in nature. Even though densification is a common pattern, it tends to result in deterioration over time due to the additional stress it adds to the infrastructure and to the built environment. Without better planning of built and open spaces, additional infrastructure capacity, and improved construction quality, densification is likely to result in slumification.

The construction of additional structures, or of additional components to existing structures, can be observed as households increase their living spaces in informal settlements to provide for a growing family. Particularly, this begins to occur as adult children start their own nuclear families through the sub-division of existing spaces and the creation of new units. As one can see in Figure 6, in Colonia Rancho Nuevo, only 40 percent of the lots contained a single household:

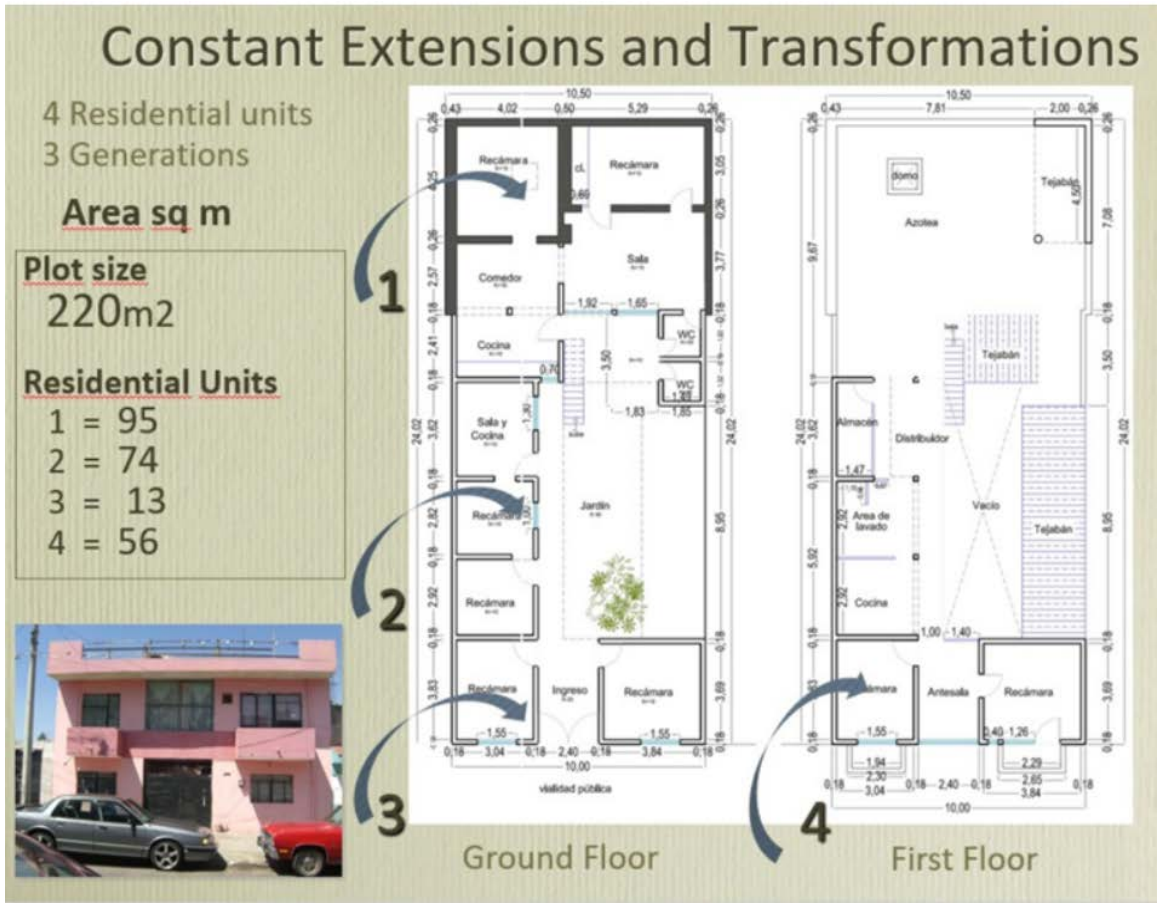

Figure 6. Consolidation in Rancho Nuevo, Guadalajara with household living space expansion to create four family residential units (for adult children and grandchildren) The numbers 1 to 4 indicate the sequence of household occupation of lot and dwelling space. (Diagram courtesy of Dr. Edith Jiménez) ${ }^{6}$.

${ }^{6}$ This diagram is from a presentation delivered by Dr. Edith Jiménez at the Mid-Semester International Workshop "Housing Market Function and Dysfunction in Consolidated Self-help neighborhoods: Towards Smart Densification", March 18 to 19, 2014, at the Lyndon B. Johnson School of Public Affairs, UT Austin. 
the majority house between two and four households. To manage the increase in resident population, the owners may add additional rooms and structures either in other parts of the property or as additional stories to house the new inhabitants. Thus, a second, third, or even fourth housing unit may be added on site as each child needs their own family space. Recent research suggests, however, that the newer additional units are smaller and poorer in quality with higher levels of overcrowding (Ward, 2015b; Grajeda, 2015). And as mentioned above, these newer household living arrangements are often considered permanent but with little likelihood of individualized ownership titles, such that any major structural changes and home improvements will be difficult to achieve, leading to potential deterioration in the physical fabric. Over the 33 years of its existence the home in Figure 6 is estimated to have accommodated some 63 different household members in long-term intensive residential use. ${ }^{7}$

Illegal subdivision of existing legally developed lots to create additional buildings is another form of densification defined as casas-de-frente-e-fundo (homes in the front and at the back, see Fernandes, 2011). In such conversion, units that were once built to house single families have now been subdivided into multiple rental or ownership units. The laws surrounding such conversion vary but transforming what was once an owner-occupied, single-family house into multiple units can add stress to the built environment through overcrowding, leading to housing deterioration. In one recent study of a large established favela in São Paulo, Brazil, while $26 \%$ of surveyed residents were renters rather than owners, some $56 \%$ of lots or dwelling parcels contained renters, suggesting that petty-landlord tenant arrangements are on the rise (Stiphany et al., forthcoming). Both within favelas and in the inner-city rental tenement building continues to flourish (Figure 7).

Housing and settlement deterioration through densification can also occur in otherwise legal housing through informal processes. The conversion of legal housing to an illegal or an extralegal status can have similar negative impacts of densification leading to slumification. For example, the conjuntos habitacionais, also known as "popular housing" or "social housing" in Brazil, can become extralegal as multiple occupancy takes place where units are rented out or sold without being formally registered (Perlman, 2010). In this case, government negligence, poor maintenance, and the stress on the built environment may create slum-like conditions. Rather than consolidation and improvement, extreme deterioration and decay can occur over time.

The increase in rental housing in Latin America is strongly related to urbanization and critical to providing housing opportunities to residents in urban areas (Blanco, 2013; Blanco et al., 2014a, 2014b). However, even though rental housing provides integral opportunities to poor and low-income residents, it may also cause densification, which, of itself, may be associated with deterioration if ${ }^{7}$ Correspondence with Dr. Edith Jiménez Huerta relating to her presentation, "The Whys and Wherefores of Renting in Consolidated Colonias," at the Lyndon B. Johnson School of Public Affairs Mid-Semester International Workshop "Housing Market Function and Dysfunction in Consolidated Self-help neighborhoods: Towards Smart Densification”, March 18 to 19, 2014. 


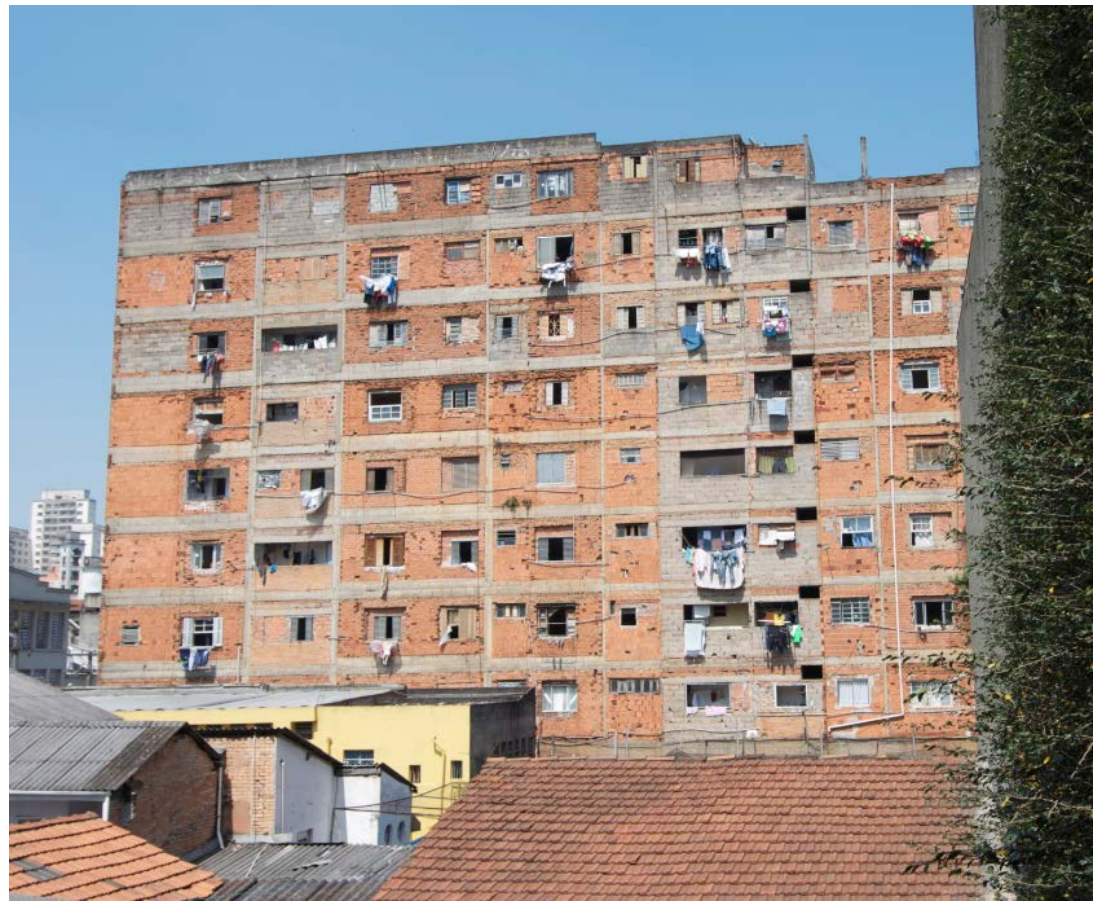

Figure 7. Cortiços (tenement rental housing), São Paulo. (Photo courtesy of Dr. Kristine Stiphany).

unplanned. According to Jiménez and Camargo (2015), within consolidated settlements, the living conditions of owners are better than renters in both Guadalajara and Bogotá. These authors also highlight that, in the absence of appropriate policies, densification manifests itself as overcrowding, particularly in rental housing. While both densification and renting can be considered natural processes in the life of an informal settlement, they can also increase overcrowding and deterioration in the absence of appropriate policies (Ward, 2015b). Indeed, the quality of rental housing in informal settlements may be poor from the onset, as landlords are less incentivized to consolidate rental units. Where rent control legislation exists, landlords are disincentivized from making improvements since they do not expect increased income (Baqai \& Ward, 2020). Renters also may have little incentive to improve their housing conditions because it does not lead to asset building. Unless the challenges associated with landlordism and the lack of incentives for renters to consolidate are prioritized, renting may continue to lead to housing deterioration and slumification over time (Ward, Jiménez, \& Di Virgilio, 2015a; Gilbert, 2003).

\subsection{Trigger Factors V. Environmental Hazards, and Natural and Man-Made Disasters}

The physical constraints associated with informal settlements discussed earlier can shape community vulnerability to both man-made and natural disasters. Settlements built on residual land can be especially prone to hazards and environmental degradation due to the nature of the land on which these structures are 
built. Due to the very nature of their location or terrain, these settlements are at a greater risk of facing increased damage from environmental hazards and disasters such as tornadoes, hurricanes, flooding, landslides, and earthquakes. Climate change is further exacerbating these issues as coastal communities become more prone to floods and storms. Over time, these environmental hazards can contribute to the deterioration of consolidated settlements.

Additionally, residents may not have the economic resources to fix their dwellings or to repair essential services after a disaster. Considering that housing in informal settlements is not insured or may not receive state recovery funds, it is most vulnerable to environmental deterioration. In extreme cases, the result can be partial abandonment of the physical space, which could lead to poorer living conditions for the remaining residents. Even in countries in the Global North, few residents in informal settlements have insurance and as in Figure 8, a tropical storm can destroy manufactured homes leading to abandonment (Durst \& Ward, 2015). Extreme effects of climate change may further worsen living conditions of informal settlements built in precarious locations such as flood plains, coastal fringes, ravines, and along hillsides subject to fire risk and landslides.

La Perla in Old San Juan, Puerto Rico, has struggled in the face of natural disasters due to its location on the coast (Figure 9). The 100-year-old settlement has housing in all types of conditions built from various materials and techniques. As Caldieron explains, "La Perla demonstrates many signs of urban decay and poverty, even though this neighborhood is located on one of the city's most valuable pieces of land" (Caldieron, 2013: p. 55). ${ }^{8}$ La Perla was particularly

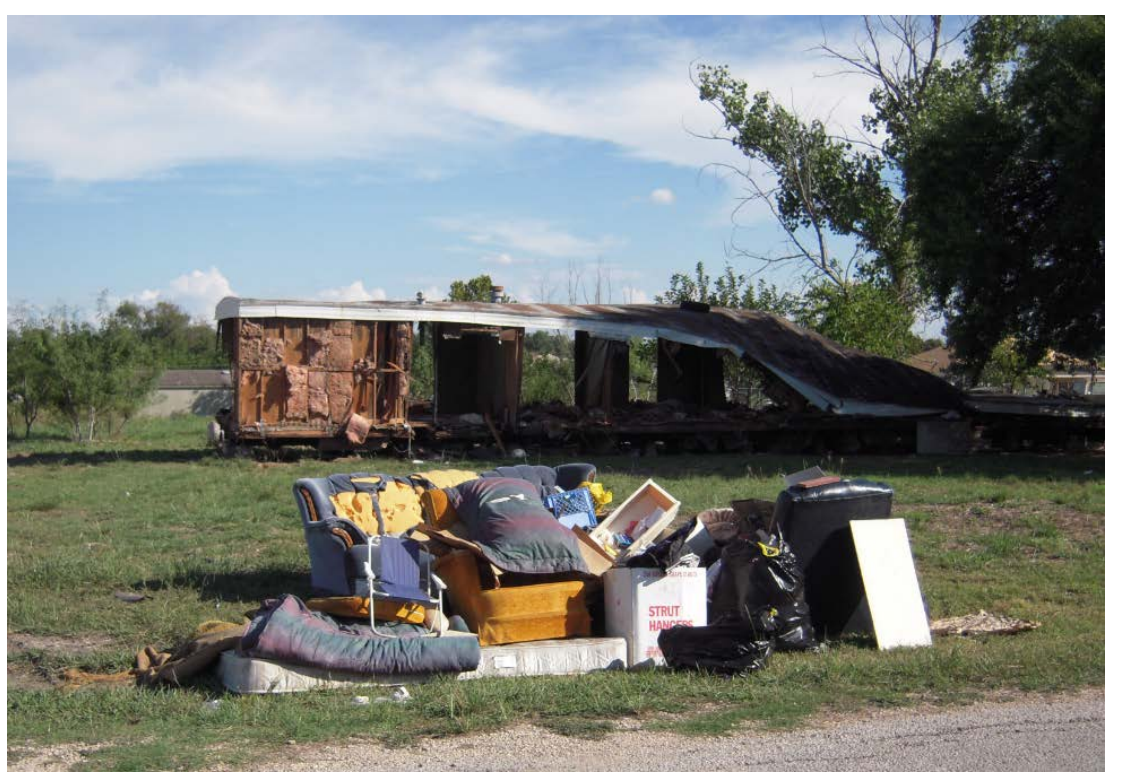

Figure 8. Post tropical-storm abandonment. Rancho Vista informal settlement, Guadalupe County, Central Texas. (Photo courtesy of Dr. Peter Ward)

${ }^{8}$ La Perla was also the neighborhood in which the Rios family lived, made famous by Oscar Lewis in his 1967 ethnographic study: La Vida: A Puerto Rican Family in the Culture of Poverty - San Juan and New York. 


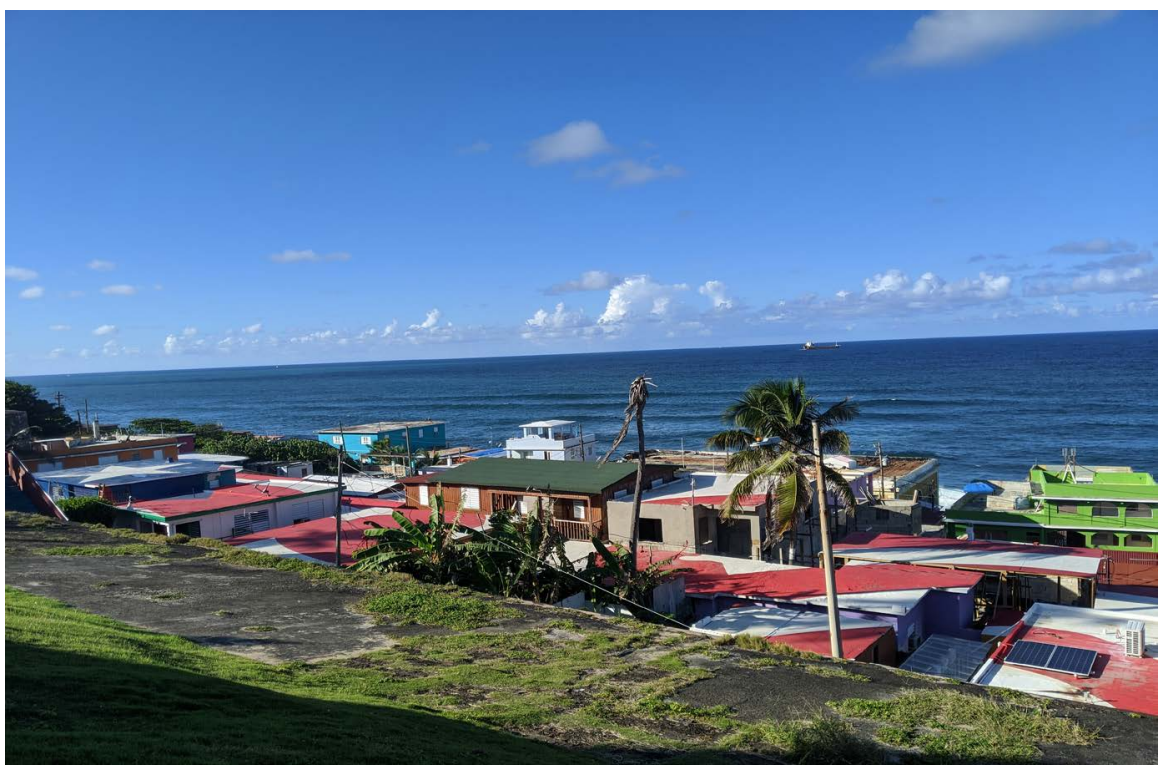

Figure 9. Due to its position close to the coast La Perla is more susceptible to damage from hurricanes. Additionally, La Perla technically rests just outside the boundary of Old San Juan which creates an additional bureaucratic layer of precariousness. (Photo courtesy of Holly Buttrey).

affected by Hurricane Maria. Residents lost access to water and electricity, similar to other communities in the island (Begnaud, 2017). La Perla's consolidation, however, is on more precarious footing at the hands of environmental disaster due to its physical location. In some cases, efforts at consolidation in La Perla have been lost to hurricanes and residents have to spend additional cost on improving their housing quality and rebuilding. This is a clear example where natural hazards have caused massive deterioration of an informal settlement with limited ways to improve conditions even though it abuts the relatively wealthy neighborhood of Old San Juan.

Los Platanitos in Santo Domingo Norte, Dominican Republic, has poor drainage and the major channel running through the settlement cannot handle significant rain events, particularly since its capacity is further limited by the blockages caused by solid waste (Figure 10(a)). This has led to flooding and landslides in the community due to the nature of the terrain and the associated constraints (Pusch, 2010: p. 32). Such environmental hazards have caused damage to existing property and negatively impacted efforts at consolidation (Figure 10(b)). In communities such as Los Platanitos, residents may not have the incentives to improve housing conditions, nor the means to counter deterioration from these repeated natural disasters, leading to slumification over time.

In another study, that of the Cristo Rey neighborhood in Santo Domingo (Grajeda, 2015), we see a larger, and in some ways more typical process of selfhelp consolidation and upgrading (Figure 11). However, here too physical constraints limit the ability to build more than a single story in 70 percent of the cases; most roofs are made of corrugated iron; lot sizes are modest, at best, with 


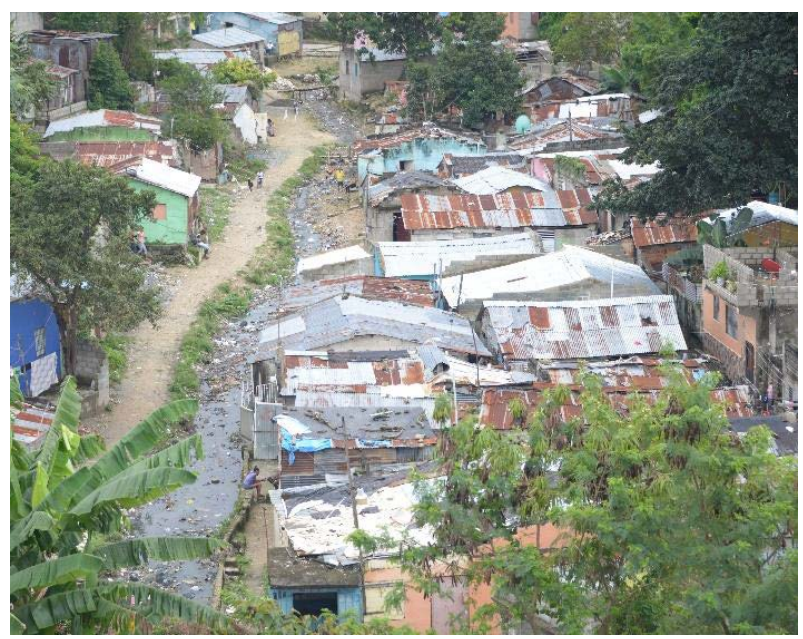

(a)

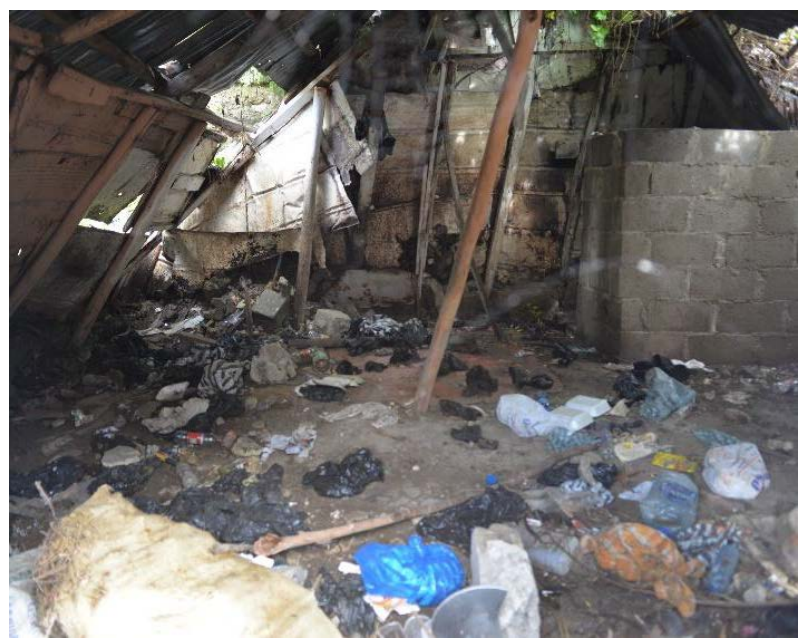

(b)

Figure 10. Due to the lack of proper drainage in Los Platanitos in Santo Domingo Norte, Dominican Republic, flooding is a common occurrence. These natural disasters are likely to disincentivize upgrading, leading to eventual deterioration as seen here. (Photos courtesy of Juan Tiney Chirix)

an average size of a 124 square meters; densities are high at around 4.9 persons per lot; few owners have formal title and 42 percent are extended households. Finally, almost one-third of lots have two households, where the second dwelling unit is invariably of significantly poorer quality with higher levels of over-crowding. Nevertheless, property values are substantial, with a median price of $\$ 40,700$ and an average price of $\$ 49,400$ (Grajeda, 2015: p. 106). Although, not yet at a downward tipping point (as outlined in Figure 1), Barrio Cristo Rey does display many of the vulnerabilities that might quickly lead to slumification, not least of which is that Santo Domingo is at risk of cyclones and hurricanes. Given its age, which dates from the 1960s, its large size of approximately 15,500 dwellings and 58,000 people, ageing resident owners whose average age is 65 years, and absent concerted housing rehab programs to prevent physical deterioration, 


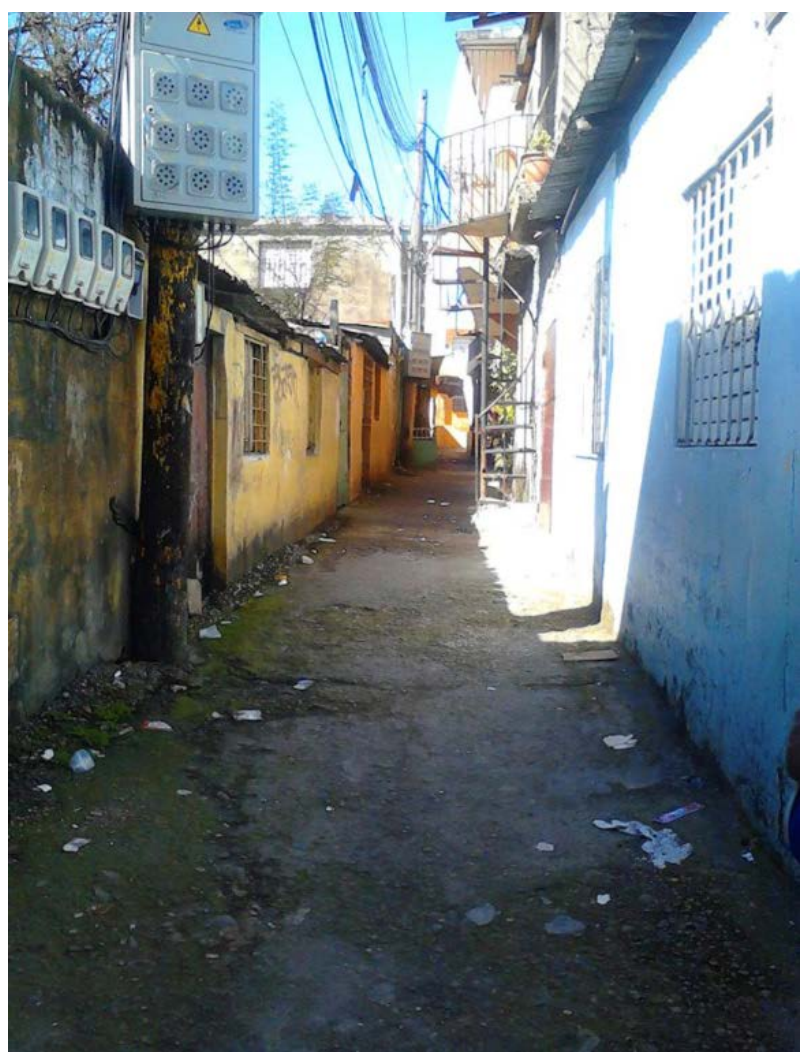

Figure 11. Side street in Cristo Rey, Santo Domingo. Consolidated settlement from the 1960s: On the Cusp of Slumification? (Photo courtesy of Dr. Erika Grajeda).

one can readily imagine that Cristo Rey could become the city's largest slum (Figure $11)$.

\section{Conclusion: Policy Mitigation, Or the Return of the Slum?}

The slum social constructions of the 1960s and 1970s which we discussed at the outset were gradually addressed by policy interventions, inspired and promoted by multilateral organizations such as the World Bank and UN-Habitat. Inter alia, these policies included regularization of infrastructure and property titles, upgrading interventions, and sites-and-services schemes. Individually or taken together, these policies were designed to assist informal settlement dwellers and self-builders in improving and consolidating their dwellings and neighborhoods, albeit gradually over a period 15 to 20 years. While many informal settlements survived, and even thrived, in Latin America, some did not, and remained as shanty towns with poor housing and environmental conditions, often at ongoing risk of eviction, fire or other hazards (Clarke \& Ward, 1980; Baqai \& Ward, 2020). Ultimately, most of these settlements were at high risk of being subjected to policies of eradication and resettlement, further stymieing incentives to make significant self-help improvements.

From the last decade of the 20th century, globalization, neoliberalism, and decentralization have shifted the policy, onus is on the state and local level to 
address these issues, and often through market-based interventions, including mass social-interest housing estates targeting lower income groups. These new estates are often plagued by their own shortcomings, which, as we observed earlier, also show visible signs of slum-like conditions and failed trajectories (Figure 1). Moreover, among the realm of consolidated informal settlements that are the focus of the LAHN studies, the Cristo Rey case described above highlights another key trigger that we have not yet discussed directly: namely the lack of appropriate policy interventions that might help to mitigate the processes of housing and community physical deterioration, i.e. slumification, in older inner-ring neighborhoods. All too often policy makers have failed to shift their attention from upgrading policies targeting newer informal settlements to include policies that would attend to the housing and community rehabilitation needs of consolidated neighborhoods that are twenty to forty years old, (see "Policy periods I \& II" in Figure 1). Today these neighborhoods are highly heterogeneous, and include mixed-tenure housing demands of owners, renters, and sharers, in what are increasingly densified neighborhoods with outdated and underperforming infrastructure, such as pot holes in the roads, poor drainage, inadequate water and power delivery systems, etc.

In these central and inner-urban neighborhoods, despite growing evidence and advocacy for interventions to meet the rising demand for low-cost rental housing, there is little to no systematic implementation of suitable policies (Gilbert, 2012, 2016; Blanco, 2013; Blanco, 2014a, 2014b; Baqai \& Ward, 2020). Nor do we see serious interest in policies that would stimulate housing and community rehab without promoting displacement (Stiphany \& Ward, 2019, 2021; Ward et al., 2015a). Similarly, there is little or no interest in policies that would extend housing titling programs or those that might mitigate title clouding caused by intestacy, informal ownership transfers, or by disagreements among heirs (Moser, 2009; Ward et al., 2011). To date, in Latin America, there has been an acute policy neglect towards the idea of in-situ rehabilitation, a neglect that might best characterize as laissez-faire. ${ }^{9}$ Since the 1990s, this changing policy environment has taken place against the backdrop of ongoing poverty, expanding informal sector labor markets, and limited prospects of upward socio-economic mobility, even among the better educated second and third generation adult populations raised in the barrios. Under the cloak of neo-liberalism, public policy approaches in the more advanced counties in the Global North have shifted away from direct low-income housing production towards "enabling policies" of housing and community rehab, mixed-tenant housing production, and "smart" sustainable approaches to neighborhood development. However, in Latin American cities similar urban development and housing programs are largely absent.

Research in the past decade has provided clear policy lines to improve equita${ }^{9}$ Interestingly laissez-faire, do nothing or do the minimum policy options were widespread during the first decades of rapid informal settlement growth, before the tide turned towards positive policy interventions at the end of the 1970s (Gilbert \& Ward, 1985). 
ble market performance, including: appropriate financing and support for sustainable housing rehab by residents themselves; the maintenance of clean titles when sold or inherited; retrofitting basic infrastructure to meet higher densities; efforts to reduce displacement and "cherry picking" of prime sites in the innerburbs by developers; and strategies to mobilize community engagement through Rights to the City organizations and legislation. However, to date, much of that research has failed to gain traction in policy-making circles. Thus, some of the older informal neighborhoods are approaching a tipping point where, absent sensitive policy intervention, they will enter a downward spiral of physical and social deterioration. Even within neighborhoods that are not yet at a tipping point, the social and physical heterogeneity is likely to create small pockets of physical deterioration at the parcel and block level. In such cases, if left unabated, one may expect more widespread deterioration throughout the community. In this paper we have identified a series of triggers that can lead to this downward spiral of slumification, namely: structural changes under neoliberalism and the "poverty of resources," heterogeneity of land access, physical constraints and deterioration, the lack of legal titles and title clouding, densification and stress on the built environment, environmental hazards, and natural and man-made disasters. We argue that unless these triggers are addressed through creative and sensitive policy making targeting these households and communities, while these settlements were not slums in the past, today's consolidated informal settlements may very well become the slums of the future.

\section{Conflicts of Interest}

The authors declare no conflicts of interest regarding the publication of this paper.

\section{References}

Abrams, C. (1966). Squatter Settlements. The Problem and the Opportunity. Washington DC: Department of Housing and Urban Development.

Baqai, A., \& Ward, P. M. (2020). Renting and Sharing in Low-Income Informal Settlements: Research Lacunae and Policy Challenges. Current Urban Studies, 8, 456-483. https://doi.org/10.4236/cus.2020.83026

Begnaud, D. (2017). “Despacito” Made This Neighborhood Famous, But Hurricane Maria Ravaged It. CBS News.

https://www.cbsnews.com/news/despacito-made-this-neighborhood-famous-but-hurri cane-maria-ravaged-it

Biles, J. J. (2009). Informal Work in Latin America: Competing Perspectives and Recent Debates. Geography Compass, 3, 214-236. https://doi.org/10.1111/j.1749-8198.2008.00188.x

Blanco, A. G. (2013). 10 razones por las cuales el alquiler es vital para los sistemas de vivienda en América Latina y el Caribe (y 10 ideas para dinamizar el mercado). Santiago de Chile: Centro UC políticas pública.

https://politicaspublicas.uc.cl/wp-content/uploads/2015/01/6-presentacion-andres-blan co-bid.pdf 
Blanco, A. G., Cibils, V. F., \& Muñoz, A. F. (2014a). Busco casa en arriendo: Promover el alquiler tiene sentido. Washington DC: Banco Interamericano de Desarrollo.

Blanco, A. G., Cibils, V. F., Miranda, A. M., \& Inter-American Development Bank (2014b). Rental Housing Wanted: Policy Options for Latin America and the Caribbean. Bethesda, MD: Fiscal and Municipal Management Division.

Caldieron, J. M. (2013). Land Tenure and the Self-Improvement of Two Latin American Informal Settlements in Puerto Rico and Venezuela. Urban Forum, 24, 49-64. https://doi.org/10.1007/s12132-012-9162-0

Carvalho, H. (2015). Políticas de vivienda de interés social en la era de la acumulación financiera: Un estudio comparado entre agentes e impactos en Brasil y México. Pittsburgh, PA: Latin American Studies Association.

Clarke, C., \& Ward, P. M. (1980). Stasis in Makeshift Housing: Perspectives from Mexico and the Caribbean. Comparative Urban Research, 8, 117-127.

Davis, M. (2006). A Planet of Slums. London: Verso. https://doi.org/10.1111/j.1540-5842.2006.00797.x

De Soto, H. (2000). The Mystery of Capital: Why Capitalism Triumphs in the West and Fails Everywhere Else. New York: Basic Books.

De Souza, F. (1999). Land Tenure Security and Housing Improvements in Recife, Brazil. Habitat International, 23, 19-33. https://doi.org/10.1016/S0197-3975(98)00033-2

Durst, N. J., \& Ward, P. M. (2015). Lot Vacancy and Property Abandonment: Colonias and Informal Subdivisions in Texas. International Journal of Housing Policy, 15, 377399. https://doi.org/10.1080/14616718.2015.1090095

Fernandes, E. (2011). Regularization of Informal Settlements in Latin America. Cambridge, MA: Lincoln Institute of Land Policy.

Gilbert, A. (1999). A Home Is Forever? Residential Mobility and Homeownership in Self Help Settlements. Environment and Planning, 31, 1073-1091. https://doi.org/10.1068/a311073

Gilbert, A. (2003). Rental Housing: An Essential Option for the Urban Poor in Developing Countries. Nairobi: UN-HABITAT.

Gilbert, A. (2007). The Return of the Slum: Does Language Matter? International Journal of Urban and Regional Research, 31, 697-713. https://doi.org/10.1111/j.1468-2427.2007.00754.x

Gilbert, A. (2012). Rental Markets and Rental Policies in Less Developed Countries. In S. Smith et al. (Eds.), The International Encyclopedia of Housing and Home (pp. 381-386). Oxford: Elsevier. https://doi.org/10.1016/B978-0-08-047163-1.00463-X

Gilbert, A. (2016). Rental Housing: The International Experience. Habitat International, 54, 173-181. https://doi.org/10.1016/j.habitatint.2015.11.025

Gilbert, A., \& Ward, P. M. (1985). Housing, the State, and the Poor: Policy and Practice in Latin American Cities. Cambridge: Cambridge University Press. (Rereleased in Paperback in 2009) https://doi.org/10.1017/CBO9780511735363

González de la Rocha, M. (2001). From the Resources of Poverty to the Poverty of Resources? The Erosion of a Survival Model. Latin American Perspectives, 28, 72-100. https://doi.org/10.1177/0094582X0102800405

González de la Rocha, M. (2007). The Construction of the Myth of Survival. Development and Change, 38, 45-66. https://doi.org/10.1111/j.1467-7660.2007.00402.x

González de la Rocha, M., Jelin, E., Perlman, J., Roberts, B., Safa, H., \& Ward, P. M. (2004). From the Marginality of the 1960s to the "New" Poverty of Today. Latin American Re- 
search Review, 39, 183-203. https://doi.org/10.1353/lar.2004.0021

Grajeda, E. (2015). The Challenges of Consolidation in Precarious Settlements of Caribbean Cities: Santo Domingo, Dominican Republic. In P. M. Ward, E. R. Jiménez, \& M. Di Virgilio (Eds.), Housing Policy in Latin American Cities: A New Generation of Strategies and Approaches for 2016 UN-HABITAT III (pp. 95-112). London: Routledge.

Hackworth, J. (2007). The Neoliberal City: Governance, Ideology, and Development in American Urbanism. Ithaca, NY: Cornell University Press.

Harvey, D. (2006). Neo-Liberalism and the Restoration of Class Power. Spaces of Global Capitalism: A Theory of Uneven Geographical Development. London: Verso.

INVI Instituto Nacional de Vivienda (Mexico) (1958). Herradura de tugurios: Problemas y soluciones. Mexico City: Agency Publication.

INVI Instituto Nacional de Vivienda (Mexico) (1968). Una Ciudad Perdida. Mexico City: Agency Publication.

Jiménez, E. R., \& Camargo, A. (2015). Rental Markets and Housing Policies in Consolidated Informal Settlements. In P. M. Ward, E. R. Jiménez, \& M. Di Virgilio (Eds.), Housing Policy in Latin American Cities: A New Generation of Strategies and Approaches for 2016 UN-HABITAT III (pp. 263-285). London: Routledge.

Katz, B., Lang, R., \& Berube, A. (2006). Redefining Urban and Suburban America: Evidence from Census 2000. Washington DC: The Brookings Institution.

Klaufus, C. (2015). Introduction: Taking Up Residency Spatial Reconfigurations and the Struggle to Belong in Urban Latin America. In C. Klaufus, \& A. Ouweneel (Eds.), Housing and Belonging in Latin America (pp. 1-20). New York: Berghahn Books. https://doi.org/10.2307/j.ctt9qdb7t.5

Kneebone, K., \& Berube, A. (2013). Confronting Suburban Poverty in America. Washington DC: Brookings Institution Press.

Leeds, A., \& Leeds, E. (1976). Accounting for Behavioural Differences: Three Political Systems and the Response to Squatters in Brazil, Peru and Chile. In J. Walton, \& L. H. Masotti (Eds.), The City in Comparative Perspective (pp. 193-248). Ultimo: Halstead Press.

Lewis, O. (1966). La Vida: A Puerto Rican Family in the Culture of Poverty. San Juan and New York: Random House.

Lloyd, P. (1979). Slums of Hope? Shantytowns of the Third World. Penguin Books.

Marosi, R. (2017). A Failed Vision. Los Angeles Times.

https://www.latimes.com/projects/la-me-mexico-housing

Mathey, K. (1992). Beyond Self-Help Housing. London: Mansell.

Mayne, A. (2017). Slums: The History of a Global Injustice. London: Reaktion Books.

Monkkonen, P. (2012). Housing Finance Reform and Increasing Socioeconomic Segregation in Mexico. International Journal of Urban and Regional Research, 36, 757-772. https://doi.org/10.1111/j.1468-2427.2011.01085.x

Moser, C. O. (2009). Ordinary Families Extraordinary Lives: Assets and Poverty Reduction in Guayaquil, 1978-2004. Washington DC: Brookings Institution Press.

Olmedo, C., \& Ward, P. M. (2016). Model Subdivisions: The New Face of Developer Lot Sales for Low-Income Colonia-Type Housing in Texas. Land Use Policy, 52, 181-194. https://doi.org/10.1016/j.landusepol.2015.12.003

Perlman, J. E. (1976). The Myth of Marginality. Berkeley, CA: University of California Press.

Perlman, J. E. (2010). Favela: Four Decades of Living on the Edge in Rio de Janeiro. Oxford: Oxford University Press. 
Portes, A. (1972). Rationality in the Slums: An Essay in Interpretive Sociology. Comparative Studies in Society and History, 14, 260-286. https://doi.org/10.1017/S001041750000668X

Portes, A. (1979). Housing Policy, Urban Poverty and the State: The Favelas of Rio de Janeiro. Latin American Research Review, 14, 3-24.

Pusch, C. A. (2010). An Analysis of Informal Housing: The Case of Los Platanitos, Santo Domingo Norte, Dominican Republic. Austin, TX: University of Texas. http://sites.utexas.edu/santodomingo-informality/files/2015/09/Christeen-Pusch-2010. pdf

Reyes, A., Reyes, A., \& Daigle, C. (2020). Looking Back to Look Forward: Evolution of the Habitat Agenda and Prospects for Implementation of the New Urban Agenda. Current Urban Studies, 8, 337-363. https://doi.org/10.4236/cus.2020.82019

Roberts, B. (2015). The Consolidation of the City and Low-Income Settlements in Guatemala City. In P. M. Ward, E. R. Jiménez, \& M. Di Virgilio (Eds.), Housing Policy in Latin American Cities: A New Generation of Strategies and Approaches for 2016 UN-HABITAT III (pp. 113-133). London: Routledge.

Stiphany, K., \& Ward, P. M. (2019). Autogestão in an Era of Mass Social Housing: The Case of Brazil's Minha Casa Minha Vida-Entidades Programme. International Journal of Housing Policy, 19, 311-336. https://doi.org/10.1080/19491247.2018.1540739

Stiphany, K., \& Ward, P. M. (2021). Informal Settlement Upgrading and the Rise of Renting in São Paulo, Brazil. (Under Review)

Stokes, C. (1962). A Theory of Slums. Land Economics, 38, 187-197. https://doi.org/10.2307/3144581

Turner, J. F. C. (1967). Barriers and Channels for Housing Development in Modernizing Countries. Journal of the American Institute of Planners, 34, 354-354.

Turner, J. F. C. (1968). The Squatter Settlement: Architecture That Works. Architectural Design, 38, 355-360.

Turner, J. F. C. (1976). Housing by People: Towards Autonomy in Building Environments.

Varley, A. (2014). Normalizing Informal Settlements? Titling and the Construction of Everyday Properties. The Mid-Semester International Workshop "Housing Market Function and Dysfunction in Consolidated Self-Help Neighborhoods: Towards Smart Densification, LBJ School of Public Affairs, the University of Texas at Austin, 18-19 March 2014.

Ward, P. M. (1976). The Squatter Settlement as Slum of Housing Solution: The Evidence from Mexico City. Land Economics, 52, 330-346. https://doi.org/10.2307/3145530

Ward, P. M. (1982). Self Help Housing: A Critique. Clinton, MS: Mansell Press.

Ward, P. M. (1999). Land Regularization in Latin America: Lessons in the Social Construction of Public Policy. Storia Urbana, 88/89, 247-268.

Ward, P. M., Jiménez, E. R., Grajeda, E., \& Velázquez, C. U. (2011). Self-Help Housing Policies for Second Generation Inheritance and Succession of "The House that Mum \& Dad Built". Habitat International, 35, 467-485.

https://doi.org/10.1016/j.habitatint.2010.12.005

Ward, P. M. (2012a) A Patrimony for the Children: Low Income Homeownership and Housing (im)Mobility in Latin American Cities. Annals of the Association of American Geographers (AAAG), 102, 1489-1510. https://doi.org/10.1080/00045608.2011.628260

Ward, P. M. (2012b). Self-Help Housing: Ideas and Practice in the Americas. In B. Sanyal, L. Vale, \& C. Rosan (Eds.), Planning Ideas That Matter: Livability, Territoriality, Gover- 
nance and Reflective Practice (pp. 283-310). Cambridge, MA: MIT Press.

Ward, P. M. (2015a). A Spectrum of Policies for Housing Rehab and Community Regeneration in the "Innerburbs". In P. M. Ward, E. R. Jiménez, \& M. Di Virgilio (Eds.), Housing Policy in Latin American Cities: A New Generation of Strategies and Approaches for $2016 U N$-Habitat III (pp. 20-39). New York: Routledge.

Ward, P. M. (2015b). Latin America's “Innerburbs": Towards a New Generation of Housing Policies for Low-Income Consolidated Self-Help Settlements. In P. M. Ward, E. R. Jiménez, \& M. Di Virgilio (Eds.), Housing Policy in Latin American Cities: A New Generation of Strategies and Approaches for 2016 UN-Habitat III (pp. 1-19). New York: Routledge.

Ward, P. M., Jiménez, E. R., \& Di Virgilio, M. (2015a). Urban Regeneration and Housing Rehabilitation in Latin America's Innerburbs. In P. M. Ward, E. R. Jiménez, \& M. Di Virgilio (Eds.), Housing Policy in Latin American Cities: A New Generation of Strategies and Approaches for 2016 UN-Habitat III (pp. 286-302). New York: Routledge.

Ward, P. M., Way, H., \& Wood, L. (2015b). Protecting Homebuyers in Low-Income Communities: Evaluating the Success of Texas Legislative Reforms in the Informal Homeownership Market. Law and Social Inquiry, 41, 152-183.

https://doi.org/10.1111/lsi.12125 